\title{
Policy Implementation: E-village Budgeting in Banyuwangi Regency
}

\author{
Entang Adhy Muhtar1, Dody Hermana², Dewi Gartika3, Riki Satia Muharam ${ }^{4}$ \\ ${ }^{1}$ Departement of Public Administration, Faculty of Social and Political Sciences, Universitas Padjadjaran (email: \\ entang.am0405@gmail.com), ²Departement of Public Administration, Universitas Garut; (email: \\ admin@fisip.uniga.ac.id), ${ }^{3}$ Researcher at BP2D West Java Province (email : d_gartika@yahoo.com), ${ }^{4}$ Doctoral \\ Candidate in Public Administration at Universitas Padjadjaran \& Researcher at Center for Public Policy and \\ Public Service Studies, Universitas Padjadjaran; Lecturer at STIA CIMAHI (email : riki.satiam@gmail.com)
}

\begin{abstract}
e-Village Budgeting is an application about planning, administration and accountability of village financial management for all villages in Banyuwangi Regency which are website based and online with real time data. The purpose of making this Electronic Village Budgetting System (E-VB) application is to create transparency and accountability in village financial management. In general, the implementation of the Electronic Village Budgetting (E-VB) Policy has been running but has not been perfect. The implementor is still shackled with the old system, even though the system is new. This study aims to examine and analyze the implementation of Electronic Village Budgetting (E-VB) Policy in Banyuwangi Regency. The theory used in this study is the theory of policy implementation from Van Meter and Van Horn. The method used is a qualitative research method. The results showed that, from the aspect of resources, especially software and brainware, were still limited, from the disposition aspect there were different perceptions in the implementation of Electronic Village Budgetting. Research recommendations need "Interpretation", which is the same in terms of budgetary linkages and Information Technology (IT) in the Implementation of Electronic Village Budgetting Policy.
\end{abstract}

\section{Keywords: \\ policy; e-village; banyuwangi}

\section{Introduction}

To realize an open government, not only requires a change in character, mentality or a change in mindset among government bureaucracies and public bodies. Precisely the main need for a medium to reform the system and work patterns to accelerate changes. Mainly by implementing an electronic government or e-government system (President Joko Widodo on the Public Information Disclosure Award at the end of 2015). E-Government is defined as the use of information and communication technology for better governance. (The use of information and communications technologies (ICTs), and particularly the Internet, to achieve better government). (Source: from OECD The e-Government Imperative, 2003). 
The e-Government development policy in Indonesia is contained in Law No. 11 of 2008 concerning Electronic Information and Transactions is then technically regulated in Presidential Instruction No. 3 of 2003 concerning National Policies and Strategies for eGovernment Development in Indonesia, where there are five guidelines, namely: (1) Government Portal Infrastructure Development Guide; (2) Guide to Electronic Document Management; (3) Guidelines for the Preparation of an Institutional e-Government Development Master Plan; (4) Guidelines for Implementing a Local Government Website; (5) Guidelines on e-Government HR education and training.

Law Number 23 Year 2014 mandates the need for a technology-based Planning and Budgeting System so that it can be well integrated and able to present aspects of the process and stages of planning and budgeting implementation for Local Governments. The Indonesian KPK further stated that the e-planning application was one part of an integrated corruption prevention action plan initiated by the Corruption Prevention and Coordination Team (KPK).

Village definition according to Law No. 6 of 2014 is a legal community unit that has territorial boundaries that are authorized to regulate and manage government affairs, the interests of local communities based on community initiatives, original rights, and / or traditional rights that are recognized and respected in the government system The Unitary State of the Republic of Indonesia. And as a form of government recognition of village authority, the paradigm of village development has changed, which initially was to build a village into a village to build. This paradigm change means that the village is no longer the object of development, but must also be the subject / agent of development. To make villages able to carry out development in accordance with the characteristics, potential and needs of their communities, the government must provide guidance and assistance. This is because the quality of rural communities is generally still low. In addition, the government must also determine arrangements and arrangements in the village so that program assistance and guidance provided by the government to the village government are not misused.

Banyuwangi Regency is the largest regency in East Java Province. The land area of Banyuwangi Regency reaches 5,782.50 km2 and has a coastline of around $175.8 \mathrm{~km}$ and 10 islands, which are divided into 24 sub-districts, 189 villages and 28 villages. In implementing village financial management, the Banyuwangi District Government issued a policy on the 
use of information technology in village financial structuring and reporting, which was later called e-village bugdeting.

Seeing these conditions, the Banyuwangi Regency Government will certainly face various problems and challenges. Banyuwangi Regency's RPJMD in 2016-2021 states there are 15 strategic development issues in Banyuwangi Regency, namely (1). Lack of community access to basic quality needs; (2) Not yet optimal strengthening of social capital and PMKS handling; (3) MSME bargaining position is not yet strong and entrepreneurial resources; (4) Economic growth that has not focused on the superior sector; (5) Income and infrastructure disparities that still need to be resolved; (6) Not optimal tourism contribution to GRDP; (7) Inadequate provision of public facilities and supporting infrastructure for the economy; (8) Low access of the people to clean water and a healthy and quality environment; (9) Not yet developed the disaster management system; (10) Good quality spatial planning but not yet accompanied by proportional public green space rates; (11) Low human resource capacity in rural areas; (12) Increased affirmation of the protection of women and children and gender equality; (13) Not optimal efforts to prevent environmental pollution and natural resources; (14) Government administration is not yet optimal; and (15) Effective, efficient and information technology based public services are not yet in operation.

In accordance with the Vision of Banyuwangi Regency in 2016-2021, the Government of Banyuwangi Regency wants to realize the independence of the region by encouraging optimization in all fields. And to accelerate the implementation of these programs, the Banyuwangi District Government must improve public services through optimizing the performance of effective, integrated and sustainable Local Government agencies. As a form of policy to improve the quality of public services in Banyuwangi Regency, the Banyuwangi Regency Government develops electronic-based public services through e-Government.

E-Village budgeting is an application of the planning, administration and accountability of village financial management for all villages in Banyuwangi Regency based on websites and online with real time data. The purpose of making this Electronic Village Budgeting (E-VB) application system is to create transparency and accountability in village financial management, so as to be able to foster public trust in the performance of the village government, which impacts on the community's great willingness to play an active role in utilizing the village budget as much as possible. Its reliability is an online and integrated 
application, even the online RKPD has also reached the village. The villages in Banyuwangi no longer have Blankspot and all of them have been electrified.

However, the implementation of the Information Technology development and utilization program also faces obstacles. In general, the implementation of the Electronic Village Budgetting (E-VB) Policy is already running but is not yet perfect. The implementer is still shackled with the old system, even though the system is new. The use of the Van Meter Van Horn theory as a basis, direction, and guidance in research on the Implementation of Electronic Village Budgetting Policy, as a medium in compiling research, harmonizing and harmonizing and also explaining values and objectives which is to be achieved in research.

Contextually, Van Meter Van Horn's theory relates to what is being studied, according to its context, relating to the Implementation of Electronic Village Budgetting policies in terms of aspects: 1) Policy standards and objectives, 2) The resources and threats made available, 3 ) The quality of inter-organizational relationships, 4) The characteristics of the implementation agencies, 5) The economic, social and political environment and 6) The disposition or response of the implementers.

Based on the description above, the study discusses the Implementation of Electronic Village Budgetting Policy in Banyuwangi Regency, so the research question can be raised as follows "How is the Implementation of Electronic Village Budgetting Policy in Banyuwangi Regency?"

\section{Methods}

This research is intended to find out "How is the Implementation of Electronic Village Budgetting Policy in Banyuwangi Regency?". Therefore, the research method used is a qualitative method. The qualitative research method was chosen by the researcher with the consideration that: first, the belief that truth can be more achieved by using qualitative methods, this is in line with the opinion of Bogdan and Taylor (1992: 18-22) that : "... Through qualitative methods we can get to know people (subjects) personally and see them develop their own definition of this world, we can feel what they are experiencing in their daily struggles, can study groups and experiences that we may not know at all. And finally, qualitative methods allow us to investigate concepts that in other research approaches, the essence will be lost.

\section{Results and Discussion}


Banyuwangi Regency is located at the east end of Java Island with coordinates of $7^{\circ}$ $43^{\prime}-8^{\circ} 46^{\prime}$ LS and $113^{\circ} 53^{\prime}-114^{\circ} 38^{\prime}$ BT. The land area consists of highlands in the form of mountains which are producing regions of agricultural products, and lowlands with a variety of potential agricultural products as well as areas around the coastline along the $175.8 \mathrm{~km}$ stretching from north to south which are producing various marine biota. Banyuwangi Regency has an area of $5,782.50 \mathrm{~km} 2$ which is a forest area. The area of this forest area reaches $183,396.34$ ha or about $31.72 \%$, rice fields around 66,152 ha or $11.44 \%$, plantations with an area of about $82,143.63$ ha or $14.21 \%$, settlements with an area of about $127,454.22$ ha or $22,04 \%$, and the rest is used for roads, fields and others. Banyuwangi Regency also has 10 islands.

Banyuwangi Regency consists of 25 sub-districts, 28 sub-districts and 189 villages, 87 neighborhoods and 751 hamlets, 2,839 neighborhood units (RW) and 10,569 neighborhood units (RT). In 2018 the population of Banyuwangi Regency was 1,735,845, consisting of 864,124 women and 871,721 men, with a sex ratio of $100.9 \%$. The population is spread over 25 Subdistricts, namely Pesanggaran, Bangorejo, Purwoharjo, Tegaldlimo, Muncar, Cluring, Gambiran, Srono, Genteng, Glenmore, Kalibaru, Singojuruh, Rogojampi, Kabat, Glagah, Banyuwangi, Giri, Wongsorjo, Songgon, Genteng, Glenmore, Kalibaru, Singojuruh, Rogojampi, Kabat, Glagah, Banyuwangi, Giri, Wongsorjo, Songgon, Sempu, Kalipuro, Silipurai, Silipuroro, Silipuroro, Tegalsari, Licin and Baru District, Blimbingsari District. Banyuwangi Regency is classified as an area that is not yet densely populated. Population density in Banyuwangi Regency in 2018 is 300.19 people / km². In other words, an average of every km2 in Banyuwangi Regency is inhabited by 300 people in 2018.

Implementation of Electronic Village Budgetting Policy in Banyuwangi Regency, according to Van Meter Van Horn The implementation of the policy consists of several dimensions, namely: 1) Policy standards and objectives, 2) The resources and ancentive made available, 3) The quality of inter-organizational relationships, 4) The characteristics of the implementation agencies, 5) The economic, social and political environment and 6) The disposition or response of the implementers.

Policy standards and objectives are basically what the program or policy wants to achieve, whether tangible or not, short, medium, or long term. Clarity and policy objectives must be seen specifically so that at the end of the program the success or failure of the policy or program being carried out can be known. Policy Standard and Objective in the aspect of 
Implementation of Electronic Village Budgetting Policy in Banyuwangi Regency, Guidelines as information for the Implementation of Electronic Village Budgetting Policy in Banyuwangi Regency in the form of a Regent's decision. In general, planning for the implementation of government programs is in the form of policy regulations, master plans, master plans, or blueprints, it is known that Electronic Village Budgetting has a form of policy regulation but the scope is not as expected.

The resource component includes the number of staff, the expertise of the implementers, relevant and sufficient information to implement the policy and the fulfillment of relevant resources in the implementation of the policy, the existence of an authority that the policy can be directed to as expected, and the existence of supporting facilities that can used to carry out policy activities such as funds and infrastructure. The development and development of the Electronic Village Budgetting Policy Implementation in Banyuwangi Regency in particular is generally left to the Village Government in preparing the Budget. In this case, the leader's mindset must be directed to the same focus, namely the development and development of Electronic Village Budgetting in Banyuwangi Regency.

The Resources and Anecdive made available in the aspect of Implementation of Electronic Village Budgetting Policy in Banyuwangi Regency, from the aspect of brainware, the level of understanding is limited, Implementation of Electronic Village Budgetting Policy in Banyuwangi Regency is done through learning by doing. Although it has not yet become the main focus, HR development efforts have begun. However, the program is still concentrated on increasing ICT literacy in general such as training and has not been specialized on ICT literacy in relation to the implementation of electronic Village Budgetting. In implementing Electronic Village Budgetting in Banyuwangi Regency, non-PNS staff were recruited for users. This shows that the HR of the government apparatus in Banyuwangi Regency is still lacking.

In general, government officials have repeatedly used information and communication technology to assist their daily activities and have had a repeat pattern in their use. To be able to implement Electronic Village Budgetting in Banyuwangi Regency professionally, human resources need to be fostered so that individuals have been able to significantly improve (quantitatively stated) activity performance through the use of information and technology. From the aspect of HR management, it shows that the program 
and budget utilization are focused on infrastructure development not yet on $\mathrm{HR}$ development.

The quality of inter-organizational relationships in the implementation aspect of Electronic Village Budgetting Policy in Banyuwangi Regency, Coordination in implementing Electronic Village Budgetting in Banyuwangi in its implementation has not been synchronous when implementing Electronic Village Budgetting, when data input often occurs sudden changes, the leadership level rather difficult to correct if there is a change.

The performance of policy implementation will be greatly influenced by the right characteristics and matches with the implementing agencies. This relates to the policy context that will be implemented in several policies that are required to implement strict and disciplined policies. In other contexts a democratic and persuasive implementing agent is needed. In addition, the area coverage is an important consideration in determining the policy implementing agent.

The characteristics of the implementation agencies, in the aspect of Implementing Electronic Village Budgetting Policy in Banyuwangi Regency, the division of tasks in implementing Electronic Village Budgetting Policy in Banyuwangi Regency through normative Bupati Regulations, however the Standard Operating Procedure (SOP) needs to be improved.

The thing that needs to be considered in evaluating the performance of policy implementation is the extent to which the external environment has contributed to the success of public policy. Non-conducive social, economic and political environment can be a source of problems from the failure of policy implementation performance.

The economic, social and political environment in the aspect of the Implementation of Electronic Village Budgetting Policy in Banyuwangi Regency, "Political Will" towards the application of Electronic Village Budgetting in Banyuwangi Regency includes Law No. 11 of 2008 concerning Electronic Information and Transactions is then technically regulated in Presidential Instruction No. 3 of 2003 concerning National Policies and Strategies for eGovernment Development in Indonesia, Law Number 23 of 2014 mandates the need for technology-based Planning and Budgeting Systems.

One of the factors that influence the effectiveness of policy implementation is the attitude of the implementor. If the implementor agrees with the contents of the policy, the 
implementor will do it happily, but if their views differ from the policy makers, the implementation process will experience many problems.

The disposition or response of the implementers in the aspect of the Implementation of Electronic Village Budgetting Policy in Banyuwangi Regency, the understanding of the apparatus of the Electronic Village Budgetting Policy in Banyuwangi Regency has not been measured, that the process that must be carried out in relation to the Implementation of Electronic Village Budgetting Policy in Banyuwangi Regency has been carried out, but thus there are still differences in perceptions regarding Electronic Village Budgetting. Top management support is the key in implementing Electronic Village Budgetting Policy in Banyuwangi Regency. The commitment of the Regional Head as the bearer of development and development tasks in Banyuwangi Regency is strong enough to be able to encourage the implementation of Electronic Village Budgetting. This concrete action can be seen through the response to the issue of ICT development as a key implementation of Electronic Village Budgetting. The Banyuasin Regent e-leadership mindset should be transmitted to all leaders in the Banyuasin Regency Government so that the manifestation of an integrated and structured Electronic Village Budgetting can be realized.

\section{Conclusion}

Based on the analysis, that there are six primary characteristics that determine the Implementation of Electronic Village Budgetting Policy in Banyuwangi Regency, namely 1) Policy standards and objectives, 2) The resources and ancentives made available, 3) The quality of inter-organizational relationships, 4) The characteristics of the implementation agencies, 5) The economic, social and political environment and 6) The disposition or response of the implementers.

Recommendations that can be given from the results of the study are as follows: 1) Decisions made by the Regent regarding SOP (Standard Operational Procedure) of electronic Village Budgetting that accommodate the entire process from upstream to downstream, even up to the progress of the electronic Village Budgetting database. 2) Updating and completing the components contained in Electronic Village Budgetting in Banyuwangi Regency. 3) Leadership Commitment in the planning process is preceded by quality data to implement Electronic Village Budgetting in Banyuwangi Regency properly. 


\section{References}

Anderson, James E, 1994, Public Policy Making, Second Edition, Houghton Miffilin Company, USA.

Creswel, John. W. 1994. Research Design Qualitative \& Quantitative Approaches. Sage Publication : New Delhi.

Dunn, W. 2000. Pengantar Analisis Kebijakan Publik. Yogyakarta : Gadjah Mada University Press, Jogjakarta.

Dwijowijoto, Riant Nugroho. 2004. Kebijakan Publik Formulasi, Implementasi dan Evaluasi. Jakarta : PT Elex Media Komputindo Kelompok Gramedia.

Erwan Agus Purwanto dan Dyah Ratih Sulistyastuti, 2002. Implementasi Kebijakan Publik Konsep dan Aplikasinya di Indonesia, Gava Media.

Grindle, M. 1980. Politics and Policy implementation, in The Third World, New Jersey: Priceton University Press.

Islamy, M. Irfan. 2004. Prinsip-Prinsip Perumusan Kebijakan Negara. Jakarta : Bumi Aksara. Nugroho, Riant. 2004. Kebijakan Publik Formulasi, Implementasi dan Evaluasi. Cetakan ke2. Jakarta: Elex Media Komputindo.

Rusli, Budiman. 2013. Kebijakan Publik, membangun pelayanan publik yang responsive. Bandung : Hakim Publishing.

Van Meter dan Van Horn. 1975. The Implementation Process: A Conceptual Framework, Administration and Society.

UU no. 25 Tahun 2004 tentang Sistem Perencanaan Pembangunan Nasional.

Undang-Undang No. 11 Tahun 2008 tentang Informasi dan Transaksi Elektronik. 